\title{
Direct economic burden of patients with autoimmune encephalitis in western China
}

Aiqing Li, MD, Xue Gong, MD, Kundian Guo, MD, Jingfang Lin, MD, Dong Zhou, MD, PhD, and Zhen Hong, MD, PhD

Neurol Neuroimmunol Neuroinflamm 2020;7:e891. doi:10.1212/NXI.0000000000000891

\section{Abstract}

\section{Objective}

To analyze the cost of autoimmune encephalitis (AE) in China for the first time.

\section{Methods}

Patients who were newly diagnosed with antibody-positive AE (anti-NMDA receptor [NMDAR], anti- $\gamma$ aminobutyric acid type $B$ receptor $\left[\mathrm{GABA}_{\mathrm{B}} \mathrm{R}\right]$, antileucine-rich gliomainactivated 1 [LGI1], and anticontactin-associated protein-2 [CASPR2]) at West China Medical Center between June 2012 and December 2018 were enrolled, and a cost-of-illness study was performed retrospectively. Data on clinical characteristics, costs, and utilization of sources were collected from questionnaires and the hospital information system.

\section{Results}

Of the 208 patients reviewed, the mean direct cost per patient was renminbi (RMB) 94,129 (United States dollars [USD] 14,219), with an average direct medical cost of RMB 88,373 (USD 13,349). The average inpatient cost per patients with $\mathrm{AE}$ was RMB 86,810 (USD 13,113). The direct nonmedical cost was much lower than the direct medical cost, averaging RMB 5,756 (USD 869). The direct cost of anti-LGI1/CASPR2 encephalitis was significantly lower than that of anti-NMDAR encephalitis and anti-GABA $\mathrm{R}$ encephalitis. The length of stay in the hospital was significantly associated with the direct cost.

\section{Conclusions}

The financial burden of AE is heavy for Chinese patients, and there are significant differences between different types of $\mathrm{AE}$.
Correspondence

Dr. Hong

hongzhengoog@aliyun.com 


\section{Glossary}

$\mathbf{A E}=$ autoimmune encephalitis; $\mathbf{C A S P R 2}=$ contactin-associated protein-2; $\mathbf{G A B A}_{\mathbf{B}} \mathbf{R}=\boldsymbol{\gamma}$-aminobutyric acid receptor type $\mathrm{B} ;$ ICU = intensive care unit; IQR = interquartile range; IVIG = IV immunoglobulin; IVMP = IV methylprednisolone; LGI1 = leucine-rich glioma-inactivated $1 ; \mathbf{m R S}=$ modified Rankin Scale; NMDAR = NMDA receptor; RMB = renminbi; USD = United States dollars.

Autoimmune encephalitis $(\mathrm{AE})$ is an immune-mediated neurologic disorder ${ }^{1}$ associated with autoantibodies against intracellular neuronal antigens (e.g., $\mathrm{Hu}$ and $\mathrm{Ma} 2$ ) and autoantibodies to the neuronal surface or synaptic antigens (e.g., anti-NMDA receptor [NMDAR], antileucine-rich glioma-inactivated 1 [LGI1], anti- $\gamma$ aminobutyric acid type $B$ receptor $\left[\mathrm{GABA}_{\mathrm{B}} \mathrm{R}\right]$, and anticontactinassociated protein-2 [CASPR2]). ${ }^{2}$ An epidemiologic study in the United States indicated that the incidence rate of AE from 1995 to 2015 was 0.8 of $100,000 .^{3}$ A study in China showed that the relative frequencies of NMDAR, LGI1, GABA $\mathrm{B}_{\mathrm{B}}$, and CASPR2 antibodies in patients with $\mathrm{AE}$ were $79.7 \%, 12.8 \%, 5.6 \%$, and $1.3 \%$, respectively. ${ }^{4}$

Previous studies, including ours, showed that $16.7 \%-38.0 \%$ of patients with anti-NMDAR encephalitis had underlying neoplasms, such as ovarian teratomas, ${ }^{5,6}$ and $32.0 \%-50.0 \%$ of patients with anti-GABA $A_{B} R$ encephalitis had coexisting small cell lung cancer and other types of tumors. ${ }^{7,8}$ Most patients with $\mathrm{AE}$ respond to immunotherapy; however, some require long-term hospitalization and intensive care resources. ${ }^{5,9}$ The medical severity and long-term disabilities associated with patients with $\mathrm{AE}$ that would inevitably burden society and families have also been reported. ${ }^{5,10,11}$ Therefore, it is important to assess the economic burden of $\mathrm{AE}$ for the rational allocation of medical resources. However, few studies on such an issue have been conducted. One study in the United States ${ }^{12}$ reported the hospitalization cost of definite $\mathrm{AE}$ and probable $\mathrm{AE}$. However, this finding does not represent the status of China. To provide baseline data for evaluating the economic impact of $\mathrm{AE}$ in western China, we studied the direct medical and direct nonmedical cost of the main types of $\mathrm{AE}$ (anti-NMDAR, anti-LGI1/CASPR2, and anti-GABA ${ }_{\mathrm{B}} \mathrm{R}$ encephalitis) among Chinese patients for the first time. Notably, the costs assessed did not include indirect costs because of failure to work, sick leave for family members, and so on. The cost presented did not exclude medical insurance reimbursement. Medical insurance coverage is high in China (96.3\% in 2018) ${ }^{13}$ However, only some patients use medical insurance mainly because of the complicated refund procedure (some patients do not know how to obtain a refund) ${ }^{13}$ Medical insurance in China can reimburse only a part of the hospitalization costs (from $30.0 \%$ to $70.0 \%$, depending on different medical insurance systems) and not outpatient and nonmedical costs, which would impose a heavy burden on patients.

\section{Methods}

\section{Subjects and interviews}

Patients with a discharge diagnosis of AE between June 2012 and December 2018 (financial year 2012-2018) at the inpatient department of neurology, West China Medical Center, were identified from the hospital information system by searching the following terms: "autoimmune," "autoimmunity," "autoimmune encephalitis," "antibodies," "NMDAR," "GABA $A_{B} R$," “CASPR2," or "LGI1." We included patients who satisfied the criteria for definite (antibody-positive) $\mathrm{AE}$ according to definitions of $\mathrm{AE}$ from a recent consensus statement. ${ }^{1}$ These patients met the following diagnostic criteria for $\mathrm{AE}^{1}$ : (1) rapid onset (<3 months) of 1 or more of the 6 following symptoms-abnormal (psychiatric) behavior or cognitive dysfunction, speech dysfunction, seizures, movement disorder, decreased level of consciousness, and autonomic dysfunction or central hypoventilation and (2) positive results for one of the antibodies (anti-NMDAR, GABA ${ }_{B} R$, and LGI1/ CASPR2 antibodies) in the CSF. The exclusion criteria were as follows: (1) patients with laboratory evidence of infectious encephalitis, for example, viral (TORCH immunoglobulin M), bacterial (CSF smear and culture), mycobacterium tuberculosis (acid-fast stain), parasitic (antibody detection), or fungal and cryptococcus (CSF smear, culture and ink stain); (2) patients diagnosed with toxic-metabolic encephalopathy, brain tumor or metastasis, vitamin deficiency or alcohol-related encephalopathy, epilepsy, and/or another nervous system disease before the onset of $\mathrm{AE}$; (3) patients with positive antibodies for other AEs, such as a-amino-3-hydroxy-5-methyl-4-isoxazolpropionic acid receptors, dipeptidylpeptidase-like protein 6 , or lgLON5, or with neurologic paraneoplastic antibodies (anti$\mathrm{Hu}$, anti-Ri, anti-Yo, anti-CV2, anti-Ma, anti-amphiphysin, anti$\mathrm{Tr}$, Purkinje cell cytoplasmic antibody type 2 , and anti-glutamic acid decarboxylase); (4) patients with encephalitis of unknown cause; (5) patients diagnosed with $\mathrm{AE}$ who received treatment previously in another hospital; and (6) patients who did not agree to participate in the survey.

Resource utilization of the direct medical costs included the number of diagnostic and therapeutic services, length of stay (LOS) in the hospital, and duration of immunotherapy (IV methylprednisolone [IVMP], IV immunoglobulin [IVIG], rituximab, and cyclophosphamide). To determine contributors to a prolonged LOS, 2 neurologists (Z.H. and D.Z.) independently reviewed the charts of all prolonged $(\geq 20.0$ days) hospitalizations, with any discrepancies resolved by further review and discussion. The following categories were defined: (1) delay in diagnosis of $\geq 7.0$ days from admission, defined as lack of a secure diagnosis resulting in a delay in the initiation of immune treatment for $\mathrm{AE}$; (2) duration of inpatient immunotherapy $\geq 7.0$ days; (3) lack of a response, defined as neurologic deterioration or a lack of neurologic 
improvement after the completion of immunotherapy and resulting in $\geq 7$-day additional stay in the hospital; (4) complications (i.e., pneumonia, sepsis, and gastrointestinal bleeding) resulting in $\geq 7$-day stay in hospital; (5) modified Rankin Scale (mRS) on admission; and (6) tumor condition.

Resource utilization of direct medical costs, direct medical costs, and clinical characteristics were extracted from the hospital information system. Direct nonmedical costs and resource utilization of direct nonmedical costs were assessed by a questionnaire designed for this study. The questionnaire included 2 parts. Part A requested basic information about the patient, such as sociodemographic details and distance to our clinic. Part B assessed the means of transportation to the clinic and AE-related clinic travel expenses, costs of professional care, and diet during hospitalization. "Professional care" indicated private nurse care out of the hospital. Most of the patients in this study had visited our center outside of their hometown. The travel expenses included transportation and accommodation.

\section{Standard protocol approvals, registrations, and patient consents}

Written informed consent was obtained from the individuals or their caregivers before enrollment in the study. This study was approved by the Research Ethics Committee of West China Medical Center of Sichuan University.

\section{Estimation of costs}

In our study, the total expenditures for each patient were calculated as the sum of the direct medical costs and direct nonmedical costs due to AE-related clinic visits (whether inpatient or outpatient visits) in our center. There are 3 kinds of medical security systems, namely, urban basic medical insurance, basic medical insurance for urban residents, and new rural cooperative medical care. Because reimbursement by the different systems is highly variable in China, as stated in the Introduction section, costs as listed by the hospital before reimbursement were counted.

Direct medical costs included all inpatient and outpatient costs. Inpatient costs were grouped as treatment (immunotherapies [IVMP, IVIG, rituximab, and cyclophosphamide], antiepileptic drugs, antipsychotic drugs, anti-infective drugs, other treatment, etc.) cost, tests (MRI of the brain, EEG, antibody examination, lumbar puncture, biomedical assays, etc.), and other costs (room cost, nursing-related cost, etc.). The cost of tumor treatment was not included in these calculations. Direct nonmedical costs involved professional care, diet during hospitalization and travel expenses to the clinic, which were accessed by face-to-face questionnaire investigations.

Notably, only AE-related resource use was recorded. The initial valuation of cost items was in the Chinese currency renminbi (RMB), and the exchange rate was converted into United States dollars (USD) for reference, with an average exchange rate equaling USD $1=$ RMB 6.62 for 2018. The demographic and clinical characteristics, LOS, and inpatient costs of our cohort were compared to those of the United States cohort. ${ }^{12}$

\section{Statistical analysis}

SPSS 20.0 (SPSS Inc., Chicago, IL), as well as GraphPad Prism 8.0 (GraphPad Software Inc., San Diego, CA), was used for the statistical analyses. The $\chi^{2}$ test was used for categorical variables. The Kruskal-Wallis test was used for continuous variables. Linear regression analysis was conducted to compare direct inpatient cost and time after applying logarithmic transformation. For univariate regression analyses, 6 variables were preselected by 2 experienced neurologists (Z.H. and D.Z.) to examine their associations with direct costs (age, sex, tumor condition, mRS, LOS, and AE-related neurologic care visit), and 11 variables were preselected to examine associations with LOS (age, sex, antibody type, MRI abnormality, EEG abnormality, tumor condition, mRS at admission, complications, delay in diagnosis, lack of a response, and prolonged immune treatment). The ordinary least squares method was used.

\section{Data availability}

The authors confirm that the data supporting the findings of this study are available within the article and from the corresponding author upon reasonable request.

\section{Results}

\section{Demographic and clinical characteristics of patients}

A total of 217 patients who met the study criteria were retrospectively reviewed. Nine patients with NMDAR encephalitis declined to participate in the survey. Ultimately, 208 patients were enrolled (table 1 ). There were 155 patients in the antiNMDAR encephalitis group, 26 in the $\mathrm{GABA}_{\mathrm{B}} \mathrm{R}$ group and 27 in the LGI1/CASPR2 group. The details of anti-LGI1/ CASPR2 patients are shown in table e-3 (links.lww.com/ $\mathrm{NXI} / \mathrm{A} 315)$. Overall, the median age at admission was 29 years (102 [49.0\%] males and 106 [51.0\%] females). Some of the patients $(40.9 \%)$ chose to use medical insurance. Thirty-eight of 208 patients (18.3\%) had neoplasms. Of these 38 patients, only 1 patient with anti-GABA $\mathrm{B}$ encephalitis knew about the neoplasm before inpatient admission for AE. A total of 134 of the 208 patients (64.4\%) had other complications, and detailed information on the complications is shown in table e-2. Twenty-two of the 208 patients (11.0\%) were admitted to the intensive care unit (ICU) during their hospitalization, all of whom had ICU stays $>48$ hours. The mRS of admitted patients in the LGI1/CASPR2 group was better than that in the NMDAR and $G_{A B A} R$ groups. Only 1 patient died during hospitalization due to multiple organ failure, while 18 died during follow-up investigations. There was no significant difference in sex, complications, MRI, EEG, ICU rate or discharge disposition between the different subgroups. 
Table 1 Demographic and clinical characteristics of patients

\begin{tabular}{|c|c|c|c|c|c|}
\hline Variable & $\begin{array}{l}\text { Anti-NMDAR ( }=155 \\
[74.5 \%])\end{array}$ & $\begin{array}{l}\text { Anti-GABA }{ }_{B} R(N=26 \\
[12.5 \%])\end{array}$ & $\begin{array}{l}\text { Anti-LGI1/CASPR2 (N = } 27 \\
[13 \%])\end{array}$ & $\begin{array}{l}\text { Total }(N=208 \\
[100 \%])\end{array}$ & $\begin{array}{l}p \\
\text { Value }\end{array}$ \\
\hline Sex, male & $75 / 155$ (48.4\%) & $14 / 26(53.8 \%)$ & $13 / 27(48.1 \%)$ & $102(49.0 \%)$ & 0.87 \\
\hline Age, median (IQR), y & $25(19-37)$ & $55(41-62)$ & $44(32-58)$ & $29(20-44)$ & $<0.001$ \\
\hline Insurance, yes & $60 / 155(38.7 \%)$ & $10 / 26(38.5 \%)$ & $15 / 27(55.6 \%)$ & $85 / 208$ (40.9\%) & 0.25 \\
\hline Tumor & $28 / 155(18.1 \%)$ & $9 / 26(34.6 \%)$ & $1 / 27(3.7 \%)$ & $38 / 208(18.3 \%)$ & 0.014 \\
\hline Complication & 103/155 (66.5\%) & $17 / 26(65.4 \%)$ & 14/27 (51.9\%) & $134 / 208(64.4 \%)$ & 0.34 \\
\hline MRI, abnormality & $63 / 155(40.6 \%)$ & 9/26 (34.6\%) & 9/27 (33.3\%) & $81 / 208(38.9 \%)$ & 0.7 \\
\hline EEG, abnormality & 108/155 (69.7\%) & $15 / 26(57.7 \%)$ & $17 / 27(63 \%)$ & $140 / 208(67.3 \%)$ & 0.4 \\
\hline ICU admission & 19/155 (12.3\%) & $2 / 26(7.7 \%)$ & $1 / 27(3.7 \%)$ & $22 / 208(10.6 \%)$ & 0.27 \\
\hline $\begin{array}{l}\text { mRS on admission, median } \\
\text { (IQR) }\end{array}$ & $4(4-5)$ & $4(3-4)$ & $3(2-4)$ & $4(3-5)$ & $<0.001$ \\
\hline $\begin{array}{l}\text { mRS at discharge, median } \\
\text { (IQR) }\end{array}$ & $2(2-3)$ & $2(1-3)$ & $1(1-2)$ & $2(2-3)$ & $<0.001$ \\
\hline Discharge disposition & & & & & 0.12 \\
\hline Home & $101 / 155(65.2 \%)$ & $21 / 26(81.8 \%)$ & $23 / 27(85.2 \%)$ & $145 / 208(69.7 \%)$ & \\
\hline Other hospital & $53 / 155(34.2 \%)$ & $5 / 26(19.2 \%)$ & $4 / 27(14.8 \%)$ & $62 / 208(29.8 \%)$ & \\
\hline Inpatient death & 1/155 (0.6\%) & $0 / 29(0)$ & $0 / 33(0)$ & $1 / 208(0.5 \%)$ & \\
\hline
\end{tabular}

Abbreviations: $G A B A_{B} R=y$-aminobutyric acid receptor type B; ICU = intensive care unit; IQR = interquartile range; mRS = modified Rankin Scale; NMDAR = NMDA receptor.

Tumors included teratoma (18), lung cancer (7), adrenal adenoma (2), choriocarcinoma (1), pituitary tumor (1), renal cancer (1), diffuse glioma (1), thyroid tumor (1), mucinous cystadenoma (1), bladder cancer (1), hysteromyoma (1), pancreatic cancer (1), rectal cancer (1), and ovarian cancer (1).

Anti-LGI1/CASPR2 represents antileucine-rich glioma-inactivated $1(n=19)$, contactin-associated protein-2-positive $(n=3)$, and dual antibody $(n=5)$-positive encephalitis.

\section{Resource utilization}

\section{Neurologic care}

There were 295 hospitalizations for the 208 patients, with an average number of 1.4 per patient (range 1-7). The annual number for each patient was 0.6 (range 0.14-2). There were 516 outpatient visits for the 208 patients after their first hospitalization, with an average number of 2.5 (range 0-27) and 0.9 outpatient visits per year per patient (range 0-10). The median LOS was 24.0 days. The total number of diagnostic and therapeutic activities (outpatient and hospitalization) for each $\mathrm{AE}$ category is depicted in table 2. The highest mean number (5.3 per patient) of medical visits was incurred by patients with anti-LGI1/CASPR2 encephalitis, while patients with anti-NMDAR encephalitis had the lowest mean number (3.5 per patient) of diagnostic and therapeutic interventions. Regarding diagnostic tests, a total of 277 EEG tracings, 293 MRI scans, 312 lumbar punctures, and 257 antibody examinations were performed during hospitalizations.

\section{Immunotherapy during hospitalization}

In total, 119 of the 208 (57.2\%) patients were receiving IVMP, $170(81.7 \%)$ were receiving IVIG, and 85 (40.9\%) were receiving first-line immunotherapy containing IVMP and IVIG. Only 6 of the 208 (2.9\%) patients received second- line immunotherapy (rituximab or cyclophosphamide). The proportion of patients receiving IVIG was significantly higher in the NMDAR group than in the $\mathrm{GABA}_{\mathrm{B}} \mathrm{R}(87.7 \%$ vs $65.4 \% p$ $<0.05)$ and LGI1/CASPR2 (87.7\% vs $63.0 \% p<0.05)$ groups. The average days of IVIG use was highest in the NMDAR group (5.8 days), followed by the $\mathrm{GABA}_{B} \mathrm{R}$ group (5.4 days) and the LGI1/CASPR2 group (3.7 days). The mean number of days of IVMP use was highest in the $\mathrm{GABA}_{\mathrm{B}} \mathrm{R}$ group (3.6 days), followed by the NMDAR group (3.5 days) and the LGI1/CASPR2 group (2.3 days).

\section{Transportation and nonneurologic care}

The mean distance from the location of residence to our hospital was $250.1 \pm 402.4 \mathrm{~km}$, and all patients used transportation tools (taxi or bus) to travel to our neurology clinic. Sixty of the 208 (29.0\%) patients claimed to ask for professional care services during hospitalization. Thirty-four of the 208 (16.3\%) patients claimed to choose accommodations in Chengdu at the time of their outpatient visits.

\section{Economic burden of AE}

The financial burden of AE patients is shown in table 3. The total direct cost contained direct medical costs (inpatient costs and outpatient costs) and direct nonmedical costs. The average direct medical cost was RMB 88,373 ( $\mathrm{SD} \pm 87,909$ ), 
Table 2 Diagnostic and therapeutic services per patient by type

\begin{tabular}{|c|c|c|c|c|c|}
\hline & $\begin{array}{l}\text { Anti-NMDAR } \\
(\mathrm{N}=155)\end{array}$ & $\begin{array}{l}\text { Anti-GABA } R \\
(N=26)\end{array}$ & $\begin{array}{l}\text { Anti-LGI1/CASPR2 } \\
(\mathrm{N}=27)\end{array}$ & $\begin{array}{l}\text { Total } \\
(N=208)\end{array}$ & $\begin{array}{l}p \\
\text { Value }\end{array}$ \\
\hline Hospitalizations, mean \pm SD, number & $1.3 \pm 0.7$ & $1.7 \pm 1.2$ & $1.6 \pm 0.8$ & $1.4 \pm 0.8$ & 0.08 \\
\hline $\begin{array}{l}\text { Annual hospitalizations, mean } \pm S D \text {, } \\
\text { number }\end{array}$ & $0.5 \pm 0.5$ & $0.8 \pm 0.5$ & $0.7 \pm 0.4$ & $0.6 \pm 0.5$ & 0.002 \\
\hline LOS in the hospital, median (IQR), d & $24.0(17.0-34.0)$ & $26.0(13.0-36.0)$ & $17.0(15.0-24.0)$ & $\begin{array}{l}24.0 \\
(16.0-33.0)\end{array}$ & 0.43 \\
\hline IVMP, mean $\pm S D, d$ & $3.5 \pm 3.4$ & $3.6 \pm 4.2$ & $2.3 \pm 2.5$ & $3.3 \pm 3.4$ & 0.31 \\
\hline IVIG, mean \pm SD, d & $5.8 \pm 3.7$ & $5.4 \pm 5.3$ & $3.7 \pm 3.3$ & $5.5 \pm 3.9$ & 0.02 \\
\hline Rituximab, mean $\pm S D, d$ & $0.4 \pm 3.2$ & $1.1 \pm 5.5$ & 0 & $0.4 \pm 3.3$ & 0.4 \\
\hline Cyclophosphamide, mean \pm SD, d & $0.1 \pm 0.7$ & 0 & 0 & $0.07 \pm 0.6$ & 1 \\
\hline Outpatient visits, mean $\pm S D$, number & $2.1 \pm 4.1$ & $3.5 \pm 5.1$ & $3.7 \pm 4.5$ & $2.5 \pm 4.3$ & 0.01 \\
\hline $\begin{array}{l}\text { Annual outpatient visits, mean } \pm S D \text {, } \\
\text { number }\end{array}$ & $0.7 \pm 1.2$ & $1.6 \pm 2.3$ & $1.8 \pm 2.7$ & $0.9 \pm 1.7$ & 0.003 \\
\hline $\mathrm{MRI}$, mean $\pm \mathrm{SD}$, number & $1.3 \pm 0.5$ & $1.7 \pm 0.9$ & $1.6 \pm 0.7$ & $1.4 \pm 0.6$ & 0.04 \\
\hline 1-2 checks, proportion of patients & $97.4 \%$ & $76.9 \%$ & $92.6 \%$ & $94.2 \%$ & 0.001 \\
\hline 3-4 checks, proportion of patients & $2.6 \%$ & $23.1 \%$ & $7.4 \%$ & $5.8 \%$ & \\
\hline EEG, mean $\pm S D$, number & $1.3 \pm 0.5$ & $1.5 \pm 0.8$ & $1.3 \pm 0.4$ & $1.3 \pm 0.5$ & 0.27 \\
\hline $1-2$ checks, proportion of patients & $99.4 \%$ & $92.3 \%$ & $100 \%$ & $98.6 \%$ & 0.2 \\
\hline 3-4 checks, proportion of patients & $0.6 \%$ & $7.7 \%$ & 0 & $1.4 \%$ & \\
\hline Lumbar, mean $\pm S D$, number & $1.5 \pm 0.8$ & $1.4 \pm 0.8$ & $1.6 \pm 0.6$ & $1.5 \pm 0.8$ & 0.41 \\
\hline $1-2$ checks, proportion of patients & $91.6 \%$ & $92.3 \%$ & $96.3 \%$ & $92.3 \%$ & 0.9 \\
\hline 3-4 checks, proportion of patients & $7.7 \%$ & $7.7 \%$ & $3.7 \%$ & $7.2 \%$ & \\
\hline $5-6$ checks, proportion of patients & $0.7 \%$ & 0 & 0 & $0.5 \%$ & \\
\hline $\begin{array}{l}\text { Antibody examination, mean } \pm S D \text {, } \\
\text { number }\end{array}$ & $1.2 \pm 0.5$ & $1.3 \pm 0.5$ & $1.4 \pm 0.5$ & $1.2 \pm 0.5$ & 0.01 \\
\hline $1-2$ checks, proportion of patients & $98.1 \%$ & $96.2 \%$ & $100 \%$ & $98.1 \%$ & 0.5 \\
\hline 3-4 checks, proportion of patients & $1.4 \%$ & $3.8 \%$ & 0 & $1.4 \%$ & \\
\hline 5-6 checks, proportion of patients & $0.5 \%$ & 0 & 0 & $0.5 \%$ & \\
\hline Outpatient death, proportion of patients & $5.8 \%$ & $34.6 \%$ & 0 & $9.1 \%$ & $<0.001$ \\
\hline
\end{tabular}

Abbreviations: $\mathrm{GABA}_{B} \mathrm{R}=\mathrm{y}$-aminobutyric acid receptor type B; IVIG = IV immunoglobulin; IVMP = IV methylprednisolone; LOS = length of stay; $N M D A R=$ NMDA receptor.

Anti-LGI1/CASPR2 represents antileucine-rich glioma-inactivated $1(n=19)$, contactin-associated protein-2-positive $(n=3)$, and dual antibody $(n=5)$-positive encephalitis.

which accounted for a major $(93.9 \%)$ proportion of the total direct cost (RMB 94,129 [SD $\pm 93,427]$ ) (figure 1). The mean hospitalization cost was RMB 86,810, and the average outpatient cost was RMB 1,563. The cost of immunotherapy (81.6\%) accounted for a major proportion of the treatment cost, and the mean treatment for each patient cost more than RMB 45,000. The average direct nonmedical cost was RMB 5,756. The average travel expense (RMB 571), diet (RMB 2,286 ), and professional care (RMB 2,899) accounted for only $9.9 \%, 39.7 \%$, and $50.4 \%$ of the direct nonmedical costs, respectively (figure 1). It can be seen in table 3 that the pattern of resource use in the different categories is almost uniform. Except for the test and other costs, the main expenditure was immunotherapy, followed by anti-infective drugs and professional care.

The costs associated with outpatients differed only slightly across AE categories, in contrast with the costs associated with inpatients. The total direct cost was highest in the NMDAR group (RMB 101,863 or USD 15,387), followed by the $\mathrm{GABA}_{\mathrm{B}} \mathrm{R}$ group (RMB 91,455 or USD 13,815) and the LGI1/CASPR2 group (RMB 52,301 or USD 7,900). 
Table 3 Economic costs per patient by type

\begin{tabular}{|c|c|c|c|c|c|}
\hline Variable & Anti-NMDAR ( $N=155)$ & Anti-GABA $B(N=26)$ & $\begin{array}{l}\text { Anti-LGI1/CASPR2 (N = } \\
27)\end{array}$ & Total $(N=208)$ & $p$ Value \\
\hline Total & $\begin{array}{l}101,864 \pm 101,834 \\
(10,452-722,859)\end{array}$ & $\begin{array}{l}91,455 \pm 74,568 \\
(10,963-323,652)\end{array}$ & $\begin{array}{l}52,301 \pm 23,296 \\
(10,872-108,382)\end{array}$ & $\begin{array}{l}94,129 \pm 93,427 \\
(10,452-722,859)\end{array}$ & 0.002 \\
\hline $\begin{array}{l}\text { Direct } \\
\text { nonmedical }\end{array}$ & $6,316 \pm 7,220(804-40,250)$ & $4,711 \pm 3,504(896-13,970)$ & $\begin{array}{l}3,549 \pm 2,366 \\
(1,104-10,300)\end{array}$ & $5,756 \pm 6,479(804-40,250)$ & 0.27 \\
\hline $\begin{array}{l}\text { Professional } \\
\text { care }\end{array}$ & $3,564 \pm 6,200(0-32,200)$ & $1,262 \pm 2,937(0-10,800)$ & $659 \pm 1,646(0-5,800)$ & $2,899 \pm 5,595(0-32,200)$ & 0.01 \\
\hline Diet & $2,298 \pm 1,274(600-8,050)$ & $2,539 \pm 2,103(550-11,300)$ & $1,976 \pm 1,214(850-6,700)$ & $2,286 \pm 1,395(550-11,300)$ & 0.32 \\
\hline Travel & $455 \pm 1,019(0-7,495)$ & $911 \pm 1,827(0-8,000)$ & $913 \pm 1,856(0-8,100)$ & $571 \pm 1,284(0-8,100)$ & 0.4 \\
\hline Direct medical & $\begin{array}{l}95,548 \pm 95,527 \\
(9,452-690,609)\end{array}$ & $\begin{array}{l}86,744 \pm 72,295 \\
(10,067-309,682)\end{array}$ & $\begin{array}{l}48,753 \pm 22,599 \\
(9,768-100,710)\end{array}$ & $\begin{array}{l}88,373 \pm 87,909 \\
(9,452-690,609)\end{array}$ & 0.001 \\
\hline Outpatient & $1,254 \pm 3,451(0-29,030)$ & $3,156 \pm 8,645(0-43,395)$ & $1,798 \pm 2,437(0-10,135)$ & $1,563 \pm 4,362(0-43,395)$ & 0.01 \\
\hline Inpatient & $\begin{array}{l}94,293 \pm 95,012 \\
(9,452-690,609)\end{array}$ & $\begin{array}{l}83,588 \pm 72,379 \\
(9,162-309,679)\end{array}$ & $\begin{array}{l}46,955 \pm 21,964 \\
(9,768-100,710)\end{array}$ & $\begin{array}{l}86,810 \pm 87,520 \\
(9,162-690,609)\end{array}$ & 0.001 \\
\hline Treatment & $\begin{array}{l}50,090 \pm 34,667 \\
(3,490-231,653)\end{array}$ & $\begin{array}{l}48,334 \pm 47,029 \\
(304-179,319)\end{array}$ & $\begin{array}{l}26,722 \pm 19,416 \\
(65-71,332)\end{array}$ & $\begin{array}{l}46,837 \pm 35,631 \\
(65-231,653)\end{array}$ & 0.001 \\
\hline Immunotherapy & $\begin{array}{l}39,954 \pm 25,495 \\
(1,700-173,750)\end{array}$ & $\begin{array}{l}42,051 \pm 44,135 \\
(0-177,000)\end{array}$ & $24,572 \pm 19,467(0-69,000)$ & $\begin{array}{l}38,219 \pm 28,193 \\
(0-177,000)\end{array}$ & 0.04 \\
\hline AEDs & $2,362 \pm 4,853(0-37,178)$ & $1,098 \pm 1,262(54-4,860)$ & $202 \pm 212(0-765)$ & $1,924 \pm 4,282(0-37,178)$ & 0.002 \\
\hline $\begin{array}{l}\text { Antipsychotic } \\
\text { drugs }\end{array}$ & $573 \pm 802(0-5,666)$ & $355 \pm 467(0-1,944)$ & $205 \pm 442(0-2,095)$ & $498 \pm 740(0-5,666)$ & 0.003 \\
\hline $\begin{array}{l}\text { Anti-infective } \\
\text { drugs }\end{array}$ & $3,981 \pm 6,808(0-33,489)$ & $2,922 \pm 4,228(0-16,530)$ & $690 \pm 2,022(0-9,945)$ & $3,422 \pm 6,196(0-33,489)$ & $<0.001$ \\
\hline Other treatment & $3,221 \pm 6,111(0-58,028)$ & $1,909 \pm 3,234(0-12,046)$ & $1,052 \pm 1,562(0-5,560)$ & $2,775 \pm 5,476(0-58,028)$ & 0.019 \\
\hline Test and other & $\begin{array}{l}44,203 \pm 69,739 \\
(5,498-531,082)\end{array}$ & $\begin{array}{l}35,254 \pm 37,287 \\
(8,858-191,114)\end{array}$ & $\begin{array}{l}20,233 \pm 9,353 \\
(9,555-41,386)\end{array}$ & $\begin{array}{l}39,973 \pm 62,163 \\
(5,498-531,082)\end{array}$ & 0.15 \\
\hline
\end{tabular}

Abbreviations: $A E D=$ antiepileptic drug; $G A B A_{B} R=y$-aminobutyric acid receptor type B; NMDAR = NMDA receptor.

Numbers represent the mean \pm SD and ranges are shown in parentheses. Costs are shown in renminbi.

Anti-LGI1/CASPR2 represents antileucine-rich glioma-inactivated $1(n=19)$, contactin-associated protein-2-positive $(n=3)$, and dual antibody $(n=5)$-positive encephalitis.

Immunotherapy included IV methylprednisolone, IV immunoglobulin, rituximab, and cyclophosphamide.

Test and other included MRI of the brain, EEG, an antibody examination, lumbar puncture, biomedical assays, room cost, and nursing-related cost.

Age, sex, tumor condition, mRS, and AE-related neurologic care visit were preselected as variables for the univariate regression analyses. LOS was strongly associated with the $\log 10$ total direct cost (LOS $\left.r^{2}=0.54, p<0.001\right)$ (figure e-1, links. lww.com/NXI/A315). Age, sex, tumor condition, mRS, and AE-related neurologic care visit did not improve the proportion of variance explained. The average cumulative direct medical expenses per patient increased significantly from first admission to 3 months in patients with all types of encephalitis, while the cumulative direct medical expenses increased slightly from 3 months to 36 months (figure 2A). Moreover, the direct medical cost of anti-LGI1/CASPR2 encephalitis was significantly lower than that of anti-NMDAR and anti-GABA ${ }_{B} R$ encephalitis.

The average inpatient cost per patient in China showed a downward trend over time (figure $2 \mathrm{~B}$ ). The $\mathrm{mRS}$ for patients did not significantly change over time (data not shown). The cost for each examination, treatment and stay item did not significantly change over time (data not shown). The number of targeted tests also did not change over time. LOS exhibited a linear relationship with the financial year $\left(r^{2}=0.84\right.$, figure $2 \mathrm{C}$ ), which might explain why the inpatient cost per patient in China decreased over time.

\section{Contributors to prolonged LOS in the hospital}

Of the 136 patients with an LOS $\geq 20.0$ days, 102 were in the NMDAR group, 18 were in the $\mathrm{GABA}_{\mathrm{B}} \mathrm{R}$ group, and 16 were in the LGI1/CASPR2 group. The factors contributing to the prolonged LOS included $\mathrm{mRS}$ on admission $\geq 4(\mathrm{n}=113, p=0.02)$, complications ( $\mathrm{n}=101, p=0.03)$, delay in diagnosis ( $\geq 7$ days, $\mathrm{n}=$ $89, p=0.04)$, lack of a response $(\mathrm{n}=48, p=0.04)$, prolonged immune treatment that required inpatient immunotherapy lasting $\geq 7$ days $(\mathrm{n}=46, p=0.03)$, and tumor condition $(\mathrm{n}=31, p=0.04)$.

Of the 89 hospitalizations with a delay in establishing the diagnosis of $\mathrm{AE}, 68$ patients were in the NMDAR group, 10 


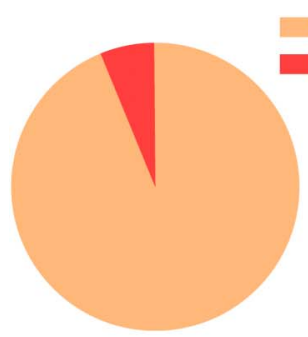

Total direct cost

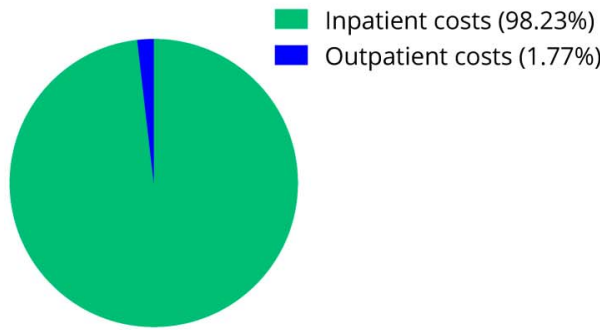

Total direct medical cost
Direct medical costs (93.88\%)

Direct nonmedical costs (6.12\%)
Professional care costs $(50.36 \%)$

Diet costs (39.72\%)

Travel costs $(9.92 \%)$

Total direct nonmedical cost

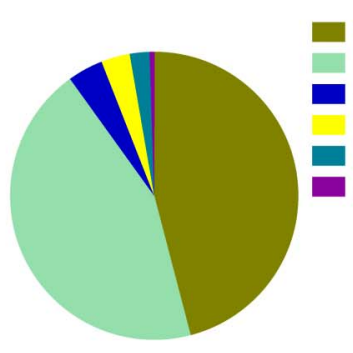

Total inpatient cost
Test and other (46.05\%)

mmunotherapy (44.03\%)

Anti-infective therapy (3.94\%)

Other treatment (3.20\%)

AEDs (2.22\%)

Antipsychotic drugs $(0.57 \%)$

The resource components of the cost are shown in all series. AED = antiepileptic drug.

were in the $\mathrm{GABA}_{\mathrm{B}} \mathrm{R}$ group, and 11 were in the LGI1/ CASPR2 group. Among the 46 patients with prolonged immune treatment, 36 had anti-NMDAR encephalitis, 9 had anti-GABA $\mathrm{B}$ encephalitis, and 1 had anti-LGI1/CASPR2 encephalitis.

\section{Discussion}

To the best of our knowledge, this is the first study to provide data on the cost of $\mathrm{AE}$ in China. A modest estimate of the mean direct cost of AE in China based on this study was RMB 94,129 (USD $14,219)$ per person. The direct cost varied widely, with an SD of USD 14,113. The mean annual income per person in Sichuan Province was RMB 20,580 (USD 3,109), ${ }^{14}$ while the mean annual income per person in China was RMB 25,974 (USD 3,924). ${ }^{15}$ Thus, $\mathrm{AE}$ is a cost-intensive disorder, and its economic burden on both patients and the healthcare system is heavy in China.

In the present study, the nonmedical direct costs were much lower than the direct medical costs, consistent with a recent economic survey on encephalitis in $\mathrm{Canada}^{16}$ and our previous study on epilepsy. ${ }^{17}$ However, different conditions have been reported by a previous study on MS patients with spasticity in Sweden, ${ }^{18}$ indicating that the largest share of total costs was direct nonmedical costs (accounting for $60.0 \%$ of the total costs). The high proportion of direct nonmedical costs (accounting for $58.0 \%$ of total costs) has also been represented in a cost-of-illness study on stroke in Italy. ${ }^{19}$ These discrepancies could be explained by differences among the diseases in nature and progression. Composition proportions of $\mathrm{AE}$ costs (figure
1) were analyzed in the present study but not yet by any other study of AE to our knowledge. Inpatient costs accounted for a major proportion (92.0\%) of the total direct costs, consistent with the findings of 2 surveys on West Nile encephalitis. ${ }^{16,20}$ Notably, immunotherapy, which is not normally covered by insurance and imposes a heavy economic burden on patients, accounted for $40.6 \%$ of the total direct cost and $44.0 \%$ of the inpatient cost in our study. Our study also compared the cost of different kinds of AE. The direct cost was lower in anti-LGI1/ CASPR2 encephalitis than in the other 2 kinds of AE. The reason for this difference may be as follows: patients in the LGI1/CASPR2 group had the shortest LOS in the hospital (median of 17.0 days, interquartile range [IQR] of 15.0-24.0), in agreement with a previous study indicating that LOS was significantly related to cost. ${ }^{12}$

Previous studies in the United States ${ }^{21-24}$ reported a shorter LOS in the hospital but more inpatient costs for patients with encephalitis of all causes than patients with AE in China in the present study. The average LOS in the hospital was 10.6-15.1 days. $^{21-24}$ The median inpatient cost was $\$ 48,852$ (IQR $\$ 23,831-\$ 104,835)$ during 1998-2010, ${ }^{21}$ and the mean inpatient expenditure was \$60,181 (SD \$130,276) during 2010-2014. ${ }^{22}$ Specific comparisons of the disease burden of $\mathrm{AE}$ in American ${ }^{12}$ and Chinese hospitals were performed (table e-1, links.lww.com/NXI/A315). The total LOS was 1.6 times greater for patients in China than for patients in the United States $^{12}$ (median of 24.0 days vs median of 15.0 days per patient). However, the inpatient cost for patients with $\mathrm{AE}$ in the United States ${ }^{12}$ was 7.7 times greater than that for patients with $\mathrm{AE}$ in China (median of 74,319 USD 
A

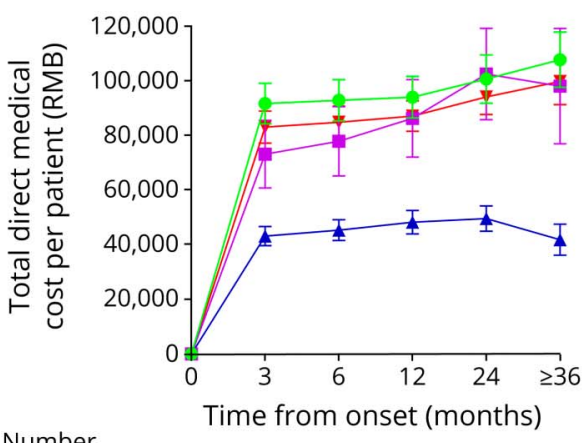

Number of patients

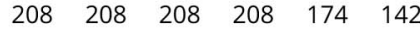

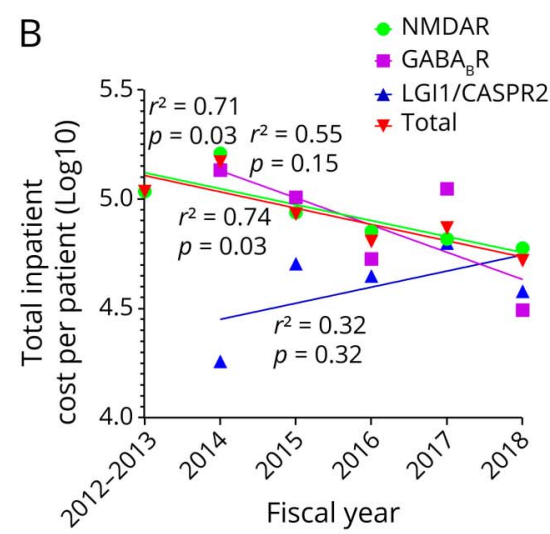

Number of patients

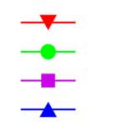

15
15
0
0

38
31
4
3

(A) The mean cumulative average direct medical cost in renminbi (RMB) per patient with different kinds of encephalitis (anti-NMDR receptor [NMDAR] encephalitis [green circle] antileucine-rich glioma-inactivated 1 [LGI1]/anticontactin-associated protein-2 [CASPR2] [blue triangle] encephalitis, and anti-y aminobutyric acid type $B$ receptor [GABA $A_{B} R$ ] encephalitis [purple square]) and all series (red triangle) from onset over time is shown. The whiskers show the standard error of the mean. (B) The mean inpatient cost (log10) per patient with different kinds of encephalitis and all series from fiscal years 2012-2018. The log10 inpatient cost exhibited a clear linear relationship with time for all series $\left(r^{2}=0.74, p=\right.$ 0.03 ) and patients with anti-NMDAR encephalitis $\left(r^{2}=0.71, p=0.03\right)$. The log10 inpatient cost per patient with anti-GABA $A_{B}$ R encephalitis $\left(r^{2}=0.54, p\right.$ $=0.20)$ and anti-LGI1/CASPR2 encephalitis $\left(r^{2}=0.32, p=0.30\right)$ over time are shown. (C) Length of stay (LOS) per patient over time. LOS exhibited a clear linear relationship with time $\left(r^{2}=\right.$ $0.84, p=0.01$ ). LGI1/CASPR2 represents antileucine-rich glioma-inactivated $1(n=19)$, contactin-associated protein-2-positive $(n=3)$, and dual antibody $(n=5)$-positive encephalitis.
$[37,569-173,020]$ vs mean of 13,113 USD or median of 9,636 USD $[6,707-13,625])$, which may mostly be due to the different price levels. However, the fact that the average annual income per person in China is only $6.6 \%$ of that in the United States should not be ignored. The lower proportion of females and lower tumor rate in anti-NMDAR encephalitis and anti$\mathrm{GABA}_{\mathrm{B}} \mathrm{R}$ encephalitis compared with those in the United States are consistent with previous studies from our center and other centers in China ${ }^{6,8,25-30}$ and may be due to the different genetic backgrounds. In addition, the lower ICU rate in anti-GABA $A_{B} R$ encephalitis is consistent with previous studies from our center ${ }^{8}$ and other centers ${ }^{30}$ in China. This study focused on antibody-positive $\mathrm{AE}$, while the United States study did include antibody-negative patients. ${ }^{12}$ According to the United States study, ${ }^{12}$ antibody-negative patients may incur a prolonged LOS in the hospital and increased medical costs given that they typically undergo consideration of other diagnoses and therefore more work-up and empiric therapy. Only $11.0 \%$ of patients were admitted to the ICU (compared to other cohorts, $43.0 \%-77.0 \%{ }^{5,12,31}$ ), which may be related to the different medical environments and economic burdens of patients, since the severity of patients in the admission stage was similar between our cohort and the American cohort ${ }^{5,12,31}$ based on the mRS evaluation. In addition, only $2.9 \%$ of patients in our cohort received a second- line immunotherapy agent, which is very different from that in United States studies (17.0\%-27.0\% of patients). ${ }^{5,32}$ This phenomenon observed in our cohort may be due to the economic reasons of patients, off-label use of second-line immunotherapy for $\mathrm{AE}$ in China, and concerns about side effects by doctors and patients. ${ }^{33}$ In addition, the inpatient cost of each $\mathrm{AE}$ patient in America ${ }^{12}$ has remained roughly constant over time. The average inpatient cost per patient in China has shown a downward trend over time (figure $2 \mathrm{~B}$ ). However, the change in the average inpatient cost per patient over time for specific kinds $\mathrm{AE}$ (such as $\mathrm{GABA}_{\mathrm{B}} \mathrm{R}$ and LGI1/ CASPR2) needs further study due to the limited number of patients. The health care costs and per capita disposable income of residents has increased over time in China (figure e-2, links.lww.com/NXI/A315). The shortened LOS, which may be due to earlier diagnosis and treatment, could partly explain the reduced costs in China. However, given the low number of patients per year and the difference in patient types over time, this phenomenon needs further verification. The difference between the above 2 countries may be explained by the different observation periods (financial years 2006-2015 in America ${ }^{12}$ vs financial years $2012-2018$ in the present study).

Notably, although a general practitioner was normally available within $5 \mathrm{~km}$ from their residence, most patients chose to 
travel more than $200 \mathrm{~km}$ for medical consultations with specialists at our tertiary center. These long trips contributed to the direct nonmedical costs of AE. This phenomenon may result from the lack of identification of $\mathrm{AE}$ by general practitioners in primary hospitals in developing countries and the lack of confidence among patients in doctors in primary hospitals, since similar results were also reported in our epilepsy economic burden study in China ${ }^{17}$ and in a previous study in India ${ }^{34}$ but not in developed countries.

The limitations of this study should be noted. First, the present study was a single-center study. However, our tertiary center is one of the largest local hospitals. Patients came from Sichuan Province and the surrounding provinces of western China, which are characterized by average socioeconomic levels. Hence, the results from our study should, in general, represent the situation of the target population. Second, the cost presented here did not exclude medical insurance reimbursement. Notably, in Sichuan Province, China, some examinations, such as PET CT, and some treatments, such as IVIG, must be fully paid for by patients themselves (even inpatients), imposing a heavy burden on patients. Third, a total of 217 patients met the study criteria, and 208 patients were enrolled. The limited number of patients with no response may have led to significant bias. Finally, due to the small numbers of patients with antiLGI1 and anti-CASPR2 encephalitis, we merged the 2 types of encephalitis for analysis, although the literature suggests that they are separate entities. ${ }^{35}$ A larger sample size study on the economic burden of anti-LGI1 encephalitis, anti-CASPR2 encephalitis and dual antibody-positive encephalitis is necessary for further details on these entities.

Moreover, it is possible that the actual cost for AE patients was underestimated. First, assistance provided by family members was not included due to the difficulty in valuing such efforts. Only a small proportion of families (29.0\%) turned to professional care during hospitalization or after discharge, even though the patients needed personal assistance, which may be based on economic and cultural factors. Second, the cost of tumor treatment was not included in these calculations. Third, our investigation did not involve indirect costs, which included sick leave, early retirement, unemployment and loss of income, for patients and individuals who accompanied the patient to the clinic because of the difficulty of accessing or evaluating such factors. Fourth, patients who received care at multiple centers and were therefore excluded from our study may have even higher costs. Finally, we did not look at how many had outpatient treatment only nor knew about costs of outpatient-only treatment or rehab costs.

In summary, this study is the first to provide information on the economic burden of AE patients in China. This research is critical for the rational allocation of medical resources to patients and healthcare payers. Future research on the strategies of the early application of targeted immune-based treatment and how to decrease LOS in the hospital is needed. It is likely that improvements in more effective and targeted immune- based treatment strategies will improve patient outcomes and decrease the economic burden of $\mathrm{AE}$ accordingly.

\section{Acknowledgment}

The authors thank all participants for their participation in our study.

\section{Study funding}

Supported by the National Natural Science Foundation of China (grants 81971213, 81671291, and 8137152) and the National Key R\&D Program of China (2018YFC1312300).

\section{Disclosure}

None of the authors have any conflicts of interest to disclose. Go to Neurology.org/NN for full disclosures.

\section{Publication history}

Received by Neurology: Neuroimmunology \& Neuroinflammation March 14, 2020. Accepted in final form August 19, 2020.

\begin{tabular}{|c|c|c|}
\hline Name & Location & Contribution \\
\hline $\begin{array}{l}\text { Aiqing } \\
\text { Li, MD }\end{array}$ & $\begin{array}{l}\text { Department of Neurology, } \\
\text { West China Medical Center, } \\
\text { Sichuan University }\end{array}$ & $\begin{array}{l}\text { Major role in the acquisition } \\
\text { of data, analyzed the data, } \\
\text { and drafted the manuscript } \\
\text { for intellectual content }\end{array}$ \\
\hline $\begin{array}{l}\text { Xue } \\
\text { Gong, } \\
\text { MD }\end{array}$ & $\begin{array}{l}\text { Department of Neurology, } \\
\text { West China Medical Center, } \\
\text { Sichuan University }\end{array}$ & $\begin{array}{l}\text { Contributed to data } \\
\text { collection }\end{array}$ \\
\hline $\begin{array}{l}\text { Kundian } \\
\text { Guo, MD }\end{array}$ & $\begin{array}{l}\text { Department of Neurology, } \\
\text { West West China Medical } \\
\text { Center, Sichuan University }\end{array}$ & $\begin{array}{l}\text { Contributed to data } \\
\text { collection }\end{array}$ \\
\hline $\begin{array}{l}\text { Jingfang } \\
\text { Lin, MD }\end{array}$ & $\begin{array}{l}\text { Department of Neurology, } \\
\text { West China Medical Center, } \\
\text { Sichuan University }\end{array}$ & $\begin{array}{l}\text { Contributed to data } \\
\text { collection }\end{array}$ \\
\hline $\begin{array}{l}\text { Dong } \\
\text { Zhou, } \\
\text { MD, PhD }\end{array}$ & $\begin{array}{l}\text { Department of Neurology, } \\
\text { West China Medical Center, } \\
\text { Sichuan University }\end{array}$ & $\begin{array}{l}\text { Interpreted the data and } \\
\text { revised the manuscript for } \\
\text { intellectual content }\end{array}$ \\
\hline $\begin{array}{l}\text { Zhen } \\
\text { Hong, } \\
\text { MD, PhD }\end{array}$ & $\begin{array}{l}\text { Department of Neurology, } \\
\text { West China Medical Center, } \\
\text { Sichuan University }\end{array}$ & $\begin{array}{l}\text { Designed and } \\
\text { conceptualized the study } \\
\text { and revised the manuscript } \\
\text { for intellectual content }\end{array}$ \\
\hline
\end{tabular}

\section{References}

1. Graus F, Titulaer MJ, Balu R, et al. A clinical approach to diagnosis of autoimmune encephalitis. Lancet Neurol 2016;15:391-404.

2. Leypoldt F, Armangue T, Dalmau J. et al. Autoimmune encephalopathies. Ann NY Acad Sci 2015;1338;94.

3. Dubey D, Pittock SJ, Kelly CR, et al. Autoimmune encephalitis epidemiology and a comparison to infectious encephalitis. Ann Neurol 2018;83:166-177.

4. Hong G, Hai R, Li C. Autoimmune encephalitis: $n$ expanding frontier of neuroimmunology. Chin Med J 2016;129:1122-1127.

5. Titulaer MJ, Lindsey MC, Iñigo G, et al. Treatment and prognostic factors for longterm outcome in patients with anti-NMDA receptor encephalitis: an observational cohort study. Lancet Neurol 2013;12:157-165.

6. Liu X, Yan B, Wang R, et al. Seizure outcomes in patients with anti-NMDAR encephalitis: a follow-up study. Epilepsia 2017;58:2104-2111.

7. Dalmau J, Rosenfeld MR. Autoimmune encephalitis update. Neuro Oncol 2014;16: $771-778$.

8. Jing L, Chen L, Ai L, et al. Encephalitis with antibodies against the GABA receptor: high mortality and risk factors. Front Neurol 2019;10:1030.

9. Newman MP, Blum S, Wong RC, et al. Autoimmune encephalitis. Intern Med J 2016; 46:148-157. 
10. Mittal MK, Rabinstein AA, Hocker SE, Pittock SJ, Wijdicks EF, McKeon A. Autoimmune encephalitis in the ICU: analysis of phenotypes, serologic findings, and outcomes. Neurocrit Care 2016;24:240-250.

11. Lee WJ, Lee ST, Moon J, et al. Tocilizumab in autoimmune encephalitis refractory to rituximab: an institutional cohort study. Neurotherapeutics 2016;13:1-9.

12. Cohen J, Sotoca J, Gandhi S, et al. Autoimmune encephalitis: a costly condition. Neurology 2019;26:e964-e972.

13. Li Z. Towards a medical insurance system with high quality and universal coverage. Chin J Health Policy 2019;13:2-8.

14. Ma JP, Wang W, Wang B, et al. Sichuan Statistical Yearbook-2018 [online]. Available at: web.sctjj.cn/tjcbw/tjnj/2018/zk/indexch.htm. Available at: Accessed June 22, 2019.

15. National Bureau of Statistics. National Data-2018 [online]. Available at: data.stats. gov.cn/easyquery.htm?cn=C01. Accessed June 22, 2019.

16. Ouhoummane N, Tchouaket E, Lowe AM, et al. Economic burden of West Nile virus disease, Quebec, Canada, 2012-2013. Emerging Infect Dis 2019;25:1943-1950.

17. Zhen H, Bo Q Xin-Tong W, et al. Economic burden of epilepsy in a developing country: a retrospective cost analysis in China. Epilepsia 2010;50:2192-2198.

18. Svensson J, Borg S, Nilsson P. Costs and quality of life in multiple sclerosis patients with spasticity. Acta Neurol Scand 2014;129:13-20.

19. Chiumente M, Gianino MM, Minniti D, et al. Burden of stroke in Italy: an economic model highlights savings arising from reduced disability following thrombolysis. Int J Stroke 2015;10:849-855.

20. Staples JE, Shankar MB, Sejvar JJ, Meltzer MI, Fischer M. Initial and long-term costs of patients hospitalized with West Nile virus disease. Am J Trop Med Hyg 2014;90:402-409.

21. Vora NM, Holman RC, Mehal JM, et al. Burden of encephalitis-associated hospitalizations in the United States, 1998-2010. Neurology 2014;82:443-451.

22. Fulton BD, Proudman DG, Sample HA, et al. Exploratory analysis of the potential for advanced diagnostic testing to reduce healthcare expenditures of patients hospitalized with meningitis or encephalitis. PLoS One 2020;15:e0226895.

23. George BP, Schneider EB, Venkatesan A, et al. Encephalitis hospitalization rates and inpatient mortality in the United States, 2000-2010. PLoS One 2014;9:e104169.
24. Nino K, Holman RC, Anderson LJ, et al. Burden of encephalitis-associated hospitalizations in the United States, 1988-1997. Clin Infect Dis 2002;35:175-182.

25. Rui $\mathrm{W}$, Xiao L, Xv L, et al. Brain magnetic resonance-imaging findings of anti-Nmethyl-d-aspartate receptor encephalitis: a cohort follow-up study in Chinese patients. J Neurol 2018;265:362-369.

26. Wei W, Jing L, Fa H, et al. Anti-NMDA receptor encephalitis: clinical characteristics, predictors of outcome and the knowledge gap in southwest China. Eur J Neurol 2016;23: 621-629.

27. Rui W, Hong G, Hai R, et al. CSF findings in patients with anti-N-methyl-d-aspartate receptor-encephalitis. Seizure 2015;29:137-142.

28. Xv L, Le $\mathrm{Z}$, Chu C, et al. Long-term cognitive and neuropsychiatric outcomes in patients with anti-NMDAR encephalitis. Acta Neurol Scand 2019;140:414-421.

29. Guan HZ, Ren HT, Yang XZ, et al. Limbic encephalitis associated with anti- $\gamma$-aminobutyric acid B receptor antibodies: a case series from China. Chin Med J (Engl) 2015;128:3023-3028.

30. Chen $\mathrm{X}, \mathrm{Liu} \mathrm{F}, \mathrm{Li} \mathrm{JM}$, et al. Encephalitis with antibodies against the $\mathrm{GABA}_{\mathrm{B}}$ receptor: seizures as the most common presentation at admission. Neurol Res 2017;39: 973-980.

31. Anastasia Z, Evgenia K, Aure 'lien V, et al. Treatment and outcome of children and adolescents with $\mathrm{N}$-methyl-d-aspartate receptor encephalitis. J Neurol 2015;262: 1859-1866.

32. de Bruijn MAAM, van Sonderen A, van Coevorden-Hameete MH, et al. Evaluation of seizure treatment in anti-LGI1, anti-NMDAR, and anti-GABA $\mathrm{B}_{\mathrm{B}} \mathrm{R}$ encephalitis. Neurology 2019;92:e2185-e2196.

33. Xu X, Lu Q, Huang Y, et al. Anti-NMDAR encephalitis: a single-center, longitudinal study in China. Neurol Neuroimmunol Neuroinflamm 2020;7:e633.

34. Thomas SV, Sarma PS, Alexander M, et al. Economic burden of epilepsy in India. Epilepsia 2010;42:1052-1060.

35. Van Sonderen A, Petit-Pedrol M, Dalmau J, et al. The value of LGI1, Caspr2 and voltage-gated potassium channel antibodies in encephalitis. Nat Rev Neurol 2017;13 290-301. 


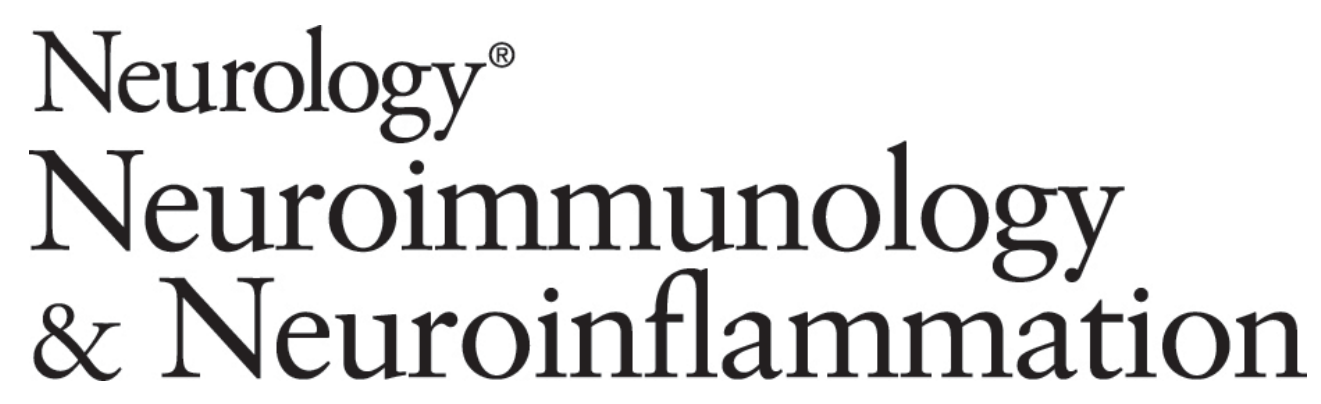

Direct economic burden of patients with autoimmune encephalitis in western China Aiqing Li, Xue Gong, Kundian Guo, et al.

Neurol Neuroimmunol Neuroinflamm 2020;7;

DOI 10.1212/NXI.0000000000000891

This information is current as of October 2, 2020

Neurol Neuroimmunol Neuroinflamm is an official journal of the American Academy of Neurology.

Published since April 2014, it is an open-access, online-only, continuous publication journal. Copyright

Copyright $\odot 2020$ The Author(s). Published by Wolters Kluwer Health, Inc. on behalf of the American

Academy of Neurology.. All rights reserved. Online ISSN: 2332-7812.

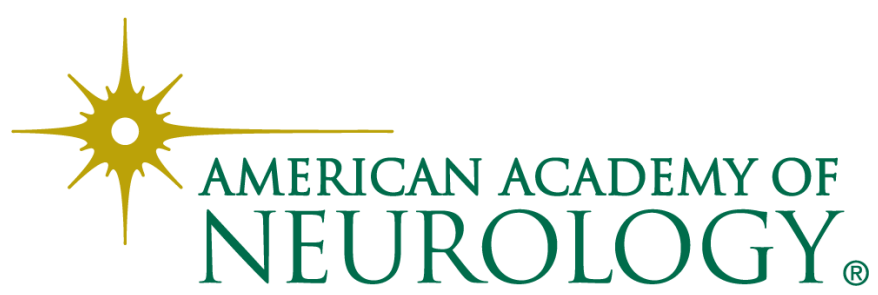




\section{Updated Information \& Services}

References

Citations

Subspecialty Collections

Permissions \& Licensing

Reprints including high resolution figures, can be found at: http://nn.neurology.org/content/7/6/e891.full.html

This article cites 33 articles, 1 of which you can access for free at: http://nn.neurology.org/content/7/6/e891.full.html\#\#ref-list-1

This article has been cited by 1 HighWire-hosted articles: http://nn.neurology.org/content/7/6/e891.full.html\#\#otherarticles

This article, along with others on similar topics, appears in the following collection(s):

Autoimmune diseases

http://nn.neurology.org//cgi/collection/autoimmune_diseases Burden of disease

http://nn.neurology.org//cgi/collection/burden_of_disease

Cost effectiveness/economic

http://nn.neurology.org//cgi/collection/cost_effectiveness_economic_ Health systems

http://nn.neurology.org//cgi/collection/health_systems

Medical care

http://nn.neurology.org//cgi/collection/medical_care

Information about reproducing this article in parts (figures,tables) or in its entirety can be found online at:

http://nn.neurology.org/misc/about.xhtml\#permissions

Information about ordering reprints can be found online:

http://nn.neurology.org/misc/addir.xhtml\#reprintsus

Neurol Neuroimmunol Neuroinflamm is an official journal of the American Academy of Neurology.

Published since April 2014, it is an open-access, online-only, continuous publication journal. Copyright

Copyright $\odot 2020$ The Author(s). Published by Wolters Kluwer Health, Inc. on behalf of the American

Academy of Neurology.. All rights reserved. Online ISSN: 2332-7812.

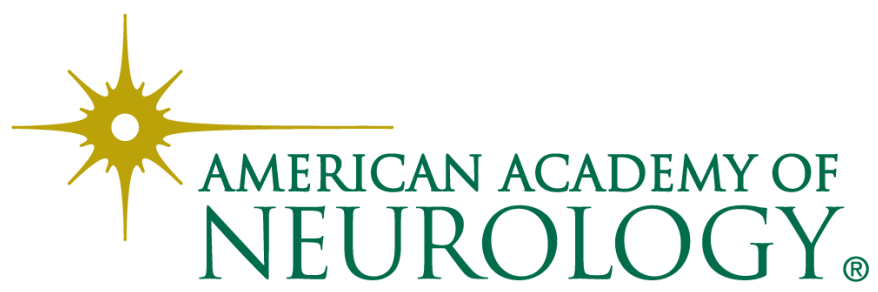

